\title{
Soul, butterfly, mythological nymph: psyche in philosophy and neuroscience
}

\author{
Alma, borboleta, ninfa mitológica: psique em filosofia e neurociência \\ Elena I. Antonakou 1,2, Lazaros C. Triarhou 1,2
}

\begin{abstract}
The term "psyche" and its derivatives - including "Psychology" and "Psychiatry" - are rooted in classical philosophy and in mythology. Over the centuries, psyche has been the subject of discourse and contemplation, and of fable; it has also come to signify, in entomology, the order of Lepidoptera. In the current surge of research on brain and mind, there is a gradual transition from the psyche (or the "soul") to the specified descriptors defined by the fields of Behavioral, Cognitive and Integrative Neuroscience.
\end{abstract}

Keywords: history; history, ancient; philosophy; neuropsychology; cognitive neuroscience.

RESUMO

O termo "psique" e seus derivados - incluindo "Psicologia" e "Psiquiatria" - estão enraizados na filosofia clássica e na mitologia. Ao longo dos séculos, a psique tem sido objeto do discurso, da contemplação, e de fábula; Também veio a significar, em entomologia, a ordem dos lepidópteros. Na atual onda de pesquisa sobre cérebro e mente, há uma transição gradual da psique (ou da "alma") para os descritores especificados definidos pelos campos da Neurociência Comportamental, Cognitiva e Integrativa.

Palavras-chave: história; história antiga; filosofia; neuropsicologia; neurociência cognitiva.

Most ancient philosophical theories are centered around the soul, or psyche. Etymologically, the word psyche derives from the verb $\psi v \dot{\chi} \chi \omega$ - which means "to cool, to blow" - as an indicator of life itself. Adopting a bird's-eye view of the terrain under discussion, and setting details aside, we trace a development towards a comprehensive conception of the soul, considered the spirit that vitalizes the world and extends over land, sea and space, through moral and mental dispositions, in all, as the organ of mind. The soul was viewed as the incorporeal or spiritual "breath" that animates (from the Latin anima, cf. "animal") the living organism. The soul was not only responsible for mental or psychological functions such as thought, perception, desire and morality, but was also involved in any vital functions that typify any living organism ${ }^{1}$.

In the Homeric epic, the way that the soul is conceived in association with life relates primarily to human beings. The soul is the spirit that lies inside the human body and departs from it upon death, exiting through the mouth. After death, the soul is transferred to Hades, the underworld, where it remains lifeless and insubstantial, intangible, nevertheless retaining the form of the physical body to which it belonged during earthly life, and becoming a reflection of it ${ }^{2}$.
The philosophical constructs of the Orphics and the Pythagoreans differ from the Homeric conception of the soul, as documented by Plato ${ }^{3}$. However, such later theories did not fundamentally affect the popular perception and prejudices about the soul. Related traditions are those of Charon and the god Hermes (or Mercury) - nicknamed the psychopomp or the one who carries souls to the underworld, where the soul is presented in the form of a bird or an insect. The appeal of those traditions becomes evident in the literary creations of Plato on the soul and eros, and of the poets of the late antiquity, such as Ovidius' Metamorphoses and the graceful fable of Apuleius, Eros and Psyche 4 .

\section{THE MYTH OF PSYCHE}

Myth itself, according to Joseph Campbell (1904-1987), represents the human search for what is true, meaningful and important. He argues that what we seek is "an experience of being alive, so that our life experiences would resonate within our innermost being and reality, so that we would actually feel the rapture of being alive." According to proponents of this theory, polytheistic myths can provide psychological insights 5 .

${ }^{1}$ University of Macedonia, Graduate Program in Neuroscience and Education, Thessalonica, Greece;

2 University of Macedonia, Laboratory of Theoretical and Applied Neuroscience, Thessalonica, Greece.

Correspondence: Lazaros C. Triarhou; University of Macedonia; Egnatia 156, Thessalonica 54636, Greece; E-mail: triarhou@uom.gr

Conflict of interest: There is no conflict of interest to declare.

Received 28 April 2016; Accepted 31 October 2016. 
Eros and Psyche, a story stemming from the Ovidian Metamorphoses, is attributed to Lucius Apuleius Madaurensis or Platonicus (2nd century A.D.). Psyche, of unmatched beauty, was the youngest daughter of a king and a queen. Her admirers neglected Venus and instead worshipped Psyche. Venus became offended and ordered her son, Eros, to work her revenge. In doing so, Eros scratched himself with one of his own darts and fell deeply in love with Psyche, disobeying his mother's order. When Psyche attempted to see Eros, she was startled to the point of wounding herself on one of the arrows in Eros's quiver. Struck with a feverish passion, she spilled hot oil from her lamp and woke him up. He instantly fled. While she tried to pursue him, he abandoned her on a riverbank. Thus began the terrible grief, from which Psyche could only escape with the aid of Eros.

The mythological adventures of Eros and Psyche were immortalized by playwrights and composers. Classical works entitled $P_{\text {syche }}$ (Figure) include an opera (lyrical tragedy) - after a Molière play - by the baroque master Jean-Baptiste Lully (1632-1687), a comic opera by Ambroise Thomas (1811-1896), a symphonic poem by César Franck (1822-1890) dedicated to his pupil Vincent d'Indy (1851-1931), and a miniature cantata by Manuel de Falla (1876-1946) dedicated to the Swedish soprano Louise Alvar (1884-1966).

\section{PSYCHE AS A BUTTERFLY}

Psyche, a mortal woman, was released from death by Zeus, the father of the gods, who took pity on her and granted her immortality ${ }^{6}$. Psyche's mythological imagery in ancient art is represented with butterfly wings, amply depicted in pottery as well. Freed from death, the body of the soul could fly freely, soaring, departing from the shackles of the chrysalis. Further, in a sarcophagus found in Patras, two children are shown holding a chrysalis, perhaps to depict the funerary character of the scene ${ }^{2}$.

The word for butterfly in formal Greek is psyche, thought to be the soul of the dead. Ancient Greeks also named the butterfly scolex ("worm"), while the chrysalis - which is the next stage of metamorphosis from a caterpillar - was called nekydallon, meaning "the shell of the dead"2. The metamorphosis of the butterfly inspired many to use butterflies as a symbol
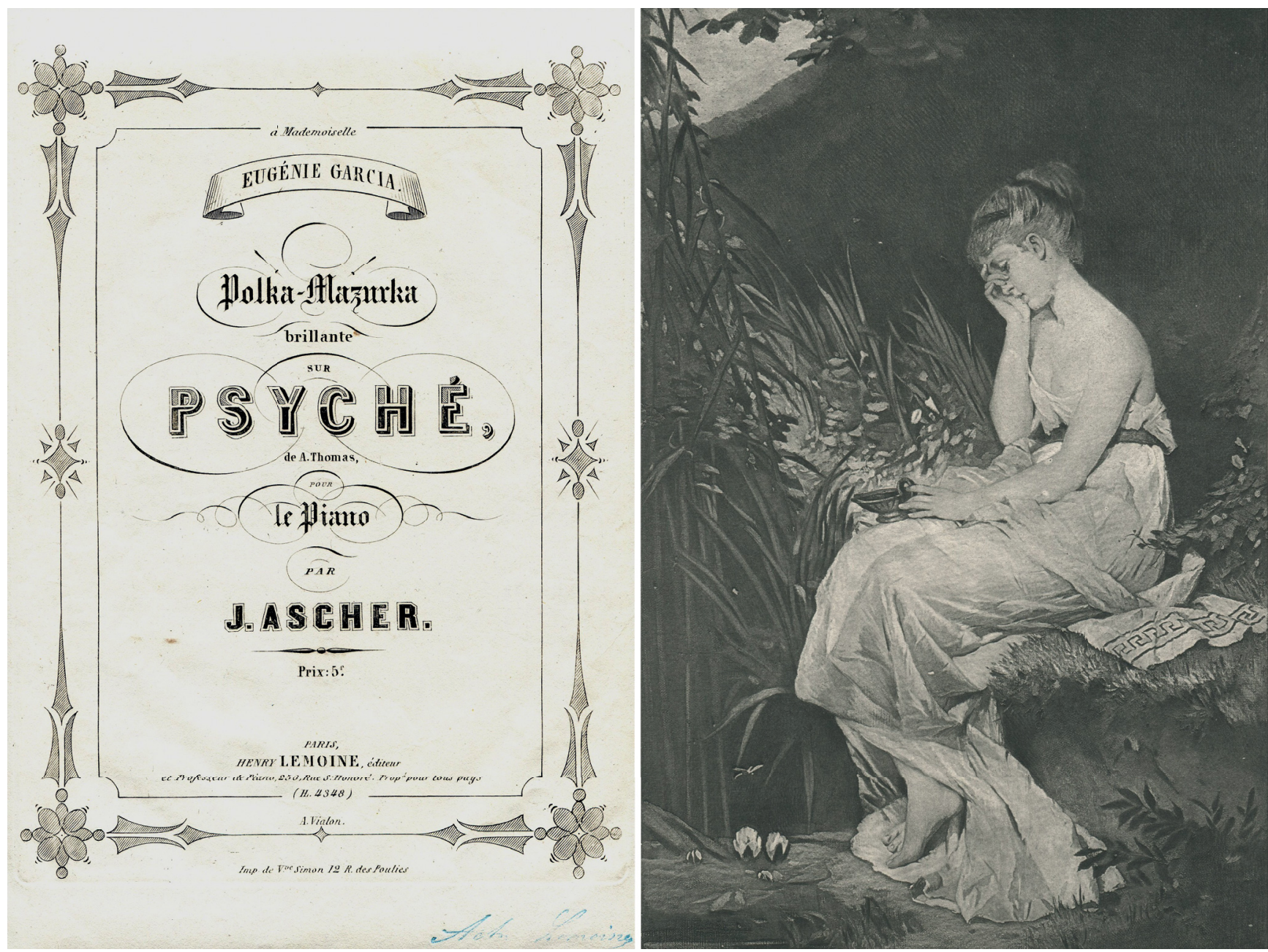

Figure. Left, a Polka-Mazurka brillante on a theme from Thomas' opera Psyché, transcribed for the pianoforte by the Dutch-Jewish composer Joseph Ascher (1829-1869). Right, a vintage engraving of the mythological Psyche, portrayed by the German painter Alfons Bodenmüller (1847-1886). (Authors' archive). 
of the soul's exit from the body. Thus, the myth of Psyche concomitantly signifies soul and butterfly. It has come to mean the story of the soul coupled with divine eros, but which must nevertheless endure tribulations before achieving immortality.

While the butterfly symbolizes awe, the moth has become the unwilling symbol for that which is ugly and negative. Other symbols identified with moths - such as insanity, for example - are also responsible for the moth's low esteem. However, the moth, attracted by the flame - just as the soul is by heavenly truth - burns itself in the flame, reflecting the trials that must be endured to eliminate the flesh before knowing the joys of the beyond ${ }^{7}$. Joris Hoefnagel (1542-1601) illustrated butterflies as human souls, and Salvador Dalí made use of the symbol of death as a European moth (the "death's-head hawkmoth" of the genus Acherontia), clearly depicting the outline of a skull on its back.

The father of modern Neuroscience, Santiago Ramón y Cajal, hunted neurons in "the garden of the grey matter" and, being an accomplished artist, meticulously catalogued the many "delicate and elaborate forms" that they take ${ }^{8}$. One of Cajal's favorite topics was the study of the human cerebral cortex; he beautifully referred to the most common neurons in this brain region - the pyramidal cells or his "psychic cells" - as "butterflies of the soul" (las mariposas del alma) ${ }^{9}$. He observed the robust dendritic trees and the ramified axons and recognized them as indispensable components of the neuron, the fundamental morphofunctional unit of the nervous system. He wrote:

"I felt at that time the most lively curiosity, somehow romantic, for the enigmatic organization of the organ of the soul. Humans, I said to myself, reign over Nature through the architectural perfection of their brains... To know the brain, I told myself in my idealistic enthusiasm, is equivalent to discovering the material course of thought and will...Like the entomologist hunting for brightly colored butterflies, my attention was drawn to the flower garden of the grey matter, which contained cells with delicate and elegant forms, the mysterious butterflies of the soul, the beating of whose wings may someday (who knows?) clarify the secret of mental life... Even from the aesthetic point of view, the nervous tissue contains the most charming attractions. Do there indeed exist, in our parks, trees more elegant and more luxurious than the Purkinje cells of the cerebellum or the psychic cell of the cortex, that is, the famous cerebral pyramid?"10

\section{LOCALIZATION OF THE SOUL}

Attempts to localize mental processes in the brain date back to ancient philosophy, beginning with Alcmaeon. Martha Nussbaum, a classicist philosopher, reminded us that philosophy was not created as a sterile, abstract, intellectual exercise, but as an active, forceful attempt to cope with life: the Hellenistic philosophical schools of Greece and Rome - Epicureans, Skeptics and Stoics - all conceived of philosophy as a way of addressing the most dolorous problems of human life ${ }^{11}$. They saw the philosopher as a compassionate physician whose act could heal, immersed in grappling with mental troubles.

In the definition of the senses, the soul infiltrates philosophical psychology. Plato is the first writer to confront the problem with a clear meaning. He defines sensation, in general, as a communion of soul and body in relation to external objects. The faculty belongs to the soul: the instrument is the body. In common, they become, by means of imagination, apprehensive of external objects. Plato considered the psyche to be the essence of a person and classified the meaning of the soul into three categories: logos (located in the head), thymos (located in the thorax) and eros (located in the abdomen $)^{12}$, while comparing them to a societal caste system. The Platonic tripartite soul is essentially similar to a state's class system because, to function well, each component must contribute, for the whole organism to function well.

The ancient Greeks contended that pneuma (air) was the vital principle of living beings. In the rete mirabile (a network of blood vessels present in the brain of certain animals, but absent from humans) this was converted to animal spirit, which was then refined in the cerebral ventricles before circulating as the basis of nervous activity. Empedocles, and apparently Pythagoras, thought that plants have souls and that human souls might animate plants. Herophilus dissected the human brain and conjectured that the soul must reside in the cerebral ventricles. Galen agreed with the tenets of Hippocrates and Herophilus but disagreed with Aristotle; the latter placed sensation in the heart. Galen favored the brain parenchyma rather than the ventricles as the location of the soul ${ }^{13}$.

In Metaphysics, Aristotle informs us that natural philosophers were a group of innovative thinkers principally interested in explaining the constitution of all matter in terms of specific basic substances. Those scholars had made the first attempt at interpreting natural phenomena, rejecting supernatural causes or mythical explanations and introducing a new critical spirit of rational discourse. They explored diverse aspects of the physical and biological world and also endeavored to solve the problem of the nature of the soul. In addition, they delved into the question of the relationship between mental activity and the body ${ }^{14}$.

According to Aristotle, the soul was not a distinctive substance; thus, it could not be separated from the body. Consequently, the body could not evolve without a soul. If we take the Aristotelian affective and intellectual soul as a paradigm of psychological processes, behavior consists of the actualization of the organism's functions. Individual behavior would occur as movement (alterations and displacements, because growth is a biological movement) taking place in relation to other entities (such as concepts, organisms or physical bodies). 
However, behavior would not be identical to such movements and changes: behavior would be the accomplishment of multiple possible functions given in a specific situation ${ }^{3}$.

\section{NEURAL EPICENTRISM AND INTEGRATIVE NEUROSCIENCE}

The field of Neuroscience has flourished as the leading scientific discipline that seeks to rigorously understand the relationship between mind and brain. In Integrative Neuroscience, each level of neural organization is seamlessly considered as part of a continuum of levels ${ }^{15}$. A fundamental impediment to Integrative Neuroscience is the sense that scientists building models at one particular scale, often see that particular scale as the epicenter of all brain function, a dynamic that Gordon has dubbed "neural epicentrism"16. Such a fragmentation has begun to change rather distinctively. Integrative Neuroscience reflects the manner in which many of the brain's processes are interrelated within and across scales, even across disciplines. As our description of the central nervous system is incomplete, such an optimistic integrative perspective begins to lift us from the jungle of detail, by shedding light on the workings of the nervous system as a whole ${ }^{15}$.

Interdisciplinary neurobiological research integrates multiple approaches, including behavior, genetics and computational modeling. Studies employing causal experimental designs to probe the functions of neural circuits (which subserve the core aspects of the behavioral domain) are becoming elemental. Mental disorders are specified by their developmental time-course, in childhood or early adulthood, highlighting the concept of differential vulnerability in the nervous system. Understanding the etiology of psychiatric conditions through basic science may lead to improved therapies.

Thus, the combination, for example, of the ontogenetic and neuroanatomical patterns of gene expression with data obtained from imaging methods render Integrative Neuroscience a large-scale science that will eventually necessitate the interaction of a broad neuroscientific base (cf. the NIH Roadmap initiative, "Re-engineering the Clinical Research Enterprise") ${ }^{17}$. A primary concern is to integrate cellular neurophysiology into macroscopic brain imaging; issues such as the consistency of activation patterns across laboratories remain to be resolved ${ }^{16}$.

Our limited understanding of the imaged brain may not have to do as much with what is measured but, rather, with the level of sophistication with which analyses take place. Multidisciplinary efforts provide the impetus to break down the boundaries and encourage a freer exchange of information across disciplines. In that respect, the study of the psyche, as a behavioral abstraction, could mean the reconstruction of an integrative system of faculties, transcending the personal tendency for "neural epicentrism"16. And as Wilder Penfield once said:

"Those who hope to solve the problem of neurophysiology of the mind are like people at the foot of a mountain. They stand in the clearings they have made on the foothills, looking up at the mountain they hope to scale. But the pinnacle is hidden in eternal clouds and many believe it can never be conquered. Surely, if the day does dawn when man has reached complete understanding of his own brain and mind, it may be his greatest conquest, his final achievement"18.

\section{References}

1. Beare JI. Greek theories of elementary cognition: from Alcmaeon to Aristotle. Oxford: Clarendon; 1906.

2. Georgoulis KD. Psyche. Helios Encyclopaedical Lexicon. 1975;24:239-46

3. Ribes-Iñesta E. Behavior and abstraction, not ostension: conceptual and historical remarks on the nature of psychology. Behav Philos. 2004;32:55-68.

4. Lewis CS. Till we have faces: a myth retold. New York: Harcourt Brace Jovanovich; 1956. p. 311.

5. Campbell J. The power of myth. New York: Doubleday; 1988. p. 5.

6. Editorial. Beyschlag's 'Psyche.' Art J. 1875;1:306-7.

7. Gagliardi RA. Butterfly and moth symbolism list 3. Insects.org. 2016 [access 2016 Apr 20]. Available from: http://www.insects.org/ced4/ symbol_list3.html

8. DeFelipe J. Cajal's butterflies of the soul: science and art. New York: Oxford University Press; 2010.

9. DeFelipe J. Cajal y sus dibujos: ciencia y arte. Arte Neurol. 2005;18:213-30.

10. Ramón y Cajal S. Recollections of my life. Birmingham, AL: Gryphon; 1988.
11. Miller RB. Facing human suffering: psychology and psychotherapy as moral engagement. Washington, DC: American Psychological Association; 2004.

12. SouryJ. Le système nerveux central; structure et fonctions; histoire critique des théories et des doctrines. Paris: G. Carré \& Naud;1899. p. 8-9.

13. Gordon E. Integrative neuroscience and personalized medicine. Oxford: Oxford University Press; 2011.

14. Crivellato E, Ribatti D. Soul, mind, brain: Greek philosophy and the birth of neuroscience. Brain Res Bull 2007;71(4):327-36. https://doi.org/10.1016/j.brainresbull.2006.09.020

15. Grillner S, Kozlov A, Kotaleski JH. Integrative neuroscience: linking levels of analyses. Curr Opin Neurobiol. 2005;15:614-21. https://doi.org/10.1016/j.conb.2005.08.017

16. Gordon E. Integrative neuroscience. Neuropsychopharmacology. 2003;28(Suppl S1):S2-S8. https://doi.org/10.1038/sj.npp.1300136

17. Insel TR, Volow ND, Landis SC, Li T-K, Battery JF, Sieving P. Limits to growth: why neuroscience needs large-scale science. Nature Neurosci. 2004;7(5):426-7. https://doi.org/10.1038/nn0504-426

18. Fromm E. The anatomy of human destructiveness. New York: Holt, Rinehart and Winston; 1973. p. 91. 